\title{
Role of prostaglandins in the suppression of apoptosis in hen granulosa cells by transforming growth factor $\alpha$
}

\author{
R. Manchanda, J-M. Kim and B. K. Tsang* \\ Reproductive Biology Unit, Departments of Obstetrics and Gynaecology, and Cellular and \\ Molecular Medicine, University of Ottawa, Ottawa Health Research Institute, The Ottawa \\ Hospital (Civic Campus), Ottawa, Ontario, Canada K1Y 4 E9
}

\begin{abstract}
Although transforming growth factor $\alpha$ (TGF- $\alpha)$ is known to be an important survival factor for granulosa cells, the cellular and molecular mechanisms involved are uncertain. The purpose of the present study was to investigate the possible involvement of prostaglandins in the anti-apoptotic action of TGF- $\alpha$. Hen granulosa cells from healthy prehierarchical follicles $(2-6 \mathrm{~mm})$ cultured in serum-free medium underwent spontaneous apoptosis as demonstrated by DNA fragmentation and nuclear chromatin condensation. TGF- $\alpha\left(20 \mathrm{ng} \mathrm{ml}^{-1}\right)$ stimulated maximum synthesis of prostaglandins (PGE and PGF) in granulosa cells and completely inhibited serum deprivation-induced apoptosis. The addition of an inhibitor of cyclooxygenase (COX; $\mathrm{N}$-(2-cyclohexyloxy-4nitrophenyl)methanesulfonamide (NS398) or ibuprofen) or phospholipase $\mathrm{A}_{2}$ (PLA $\mathrm{P}_{2}$ aristolochic acid, 2-pamylcinnamoyl amino-4-chlorobenzoic acid (ONO-RS-82) or arachidonyl triflouro methyl ketone (TFMK)), to the
\end{abstract}

culture medium markedly suppressed the TGF- $\alpha$-induced prostaglandin synthesis and significantly increased granulosa cell apoptosis. The apoptotic effect of NS398 and aristolochic acid was completely inhibited by exogenous prostaglandins $\left(\mathrm{PGF}_{2 \alpha}, \mathrm{PGE}_{1}, \mathrm{PGE}_{2}\right)$ and arachidonic acid, respectively. However, exogenous prostaglandins failed to inhibit the $\mathrm{PLA}_{2}$ inhibitor-induced apoptotic DNA fragmentation, implying that in addition to prostaglandins, arachidonic acid or leukotrienes may be important in transducing the anti-apoptotic action of TGF- $\alpha$. In the absence of exogenous TGF- $\alpha$, prostaglandins had no significant influence on granulosa cell apoptosis induced by serum withdrawal. These findings indicate that prostaglandin synthesis is a necessary, but not sufficient, event in the suppression of granulosa cell apoptosis by TGF- $\alpha$. Whether arachidonic acid or leukotrienes are important in the anti-apoptotic action of TGF- $\alpha$ in hen granulosa cells remains to be determined.

\section{Introduction}

Ovarian follicular atresia is a degenerative process that involves granulosa cell apoptosis (Hughes and Gorospe, 1991; Tilly et al., 1991b) and is controlled by gonadotrophins, steroids, cytokines and growth factors. During follicular development in the hen ovary, most of the follicles (> 99\%) become atretic and regress before reaching $9 \mathrm{~mm}$ in diameter. Follicles that develop to $>9 \mathrm{~mm}$ in diameter are committed to ovulate and generally will not succumb to atresia (Johnson et al., 1996). Although the control of follicular atresia by gonadotrophins is well documented (Hirshfield and Midgley, 1978; Chun et al., 1996), less is known about its regulation by non-gonadotrophin signals. Since follicular atresia in hens normally occurs at the prehierarchical stage of follicular development (follicular size $<9 \mathrm{~mm}$ in diameter), when granulosa cells are much less responsive to $\mathrm{FSH}$ compared with those from hierarchical follicles $(>9 \mathrm{~mm})$, the role of intraovarian local survival factors (for example, TGF- $\alpha$ ) may be crucial in

*Correspondance

Email: btsang@ohri.ca determining the fate of prehierarchical follicles (atresia versus ovulation).

TGF- $\alpha$ is a close relative of epidermal growth factor (EGF), and exerts its physiological action through binding to EGF receptors. Although TGF- $\alpha$ receptor and its ligands (EGF and TGF- $\alpha$ ) are present in the granulosa, theca interna and theca externa layers of the hen ovarian follicle throughout development, the highest concentrations are found in the smallest follicles (Onagbesan et al., 1994), indicating a potential autocrine or paracrine role of TGF- $\alpha$ in the early stage of follicular development in the hen ovary. TGF- $\alpha$ is mitogenic in hen granulosa cells and prostaglandins mediate the actions of this growth factor in several types of cell (Harrison, 1994; Li and Tsang, 1994, 1995). Membrane phospholipids such as phosphatidylcholine are metabolized by cytosolic phospholipase $A_{2}$ $\left(\mathrm{CPLA}_{2}\right)$ to arachidonic acid and lysophosphatidic acid. Cyclooxygenase (COX) then converts arachidonic acid to prostaglandins. Alternatively, arachidonic acid can be metabolized to leukotrienes via the action of lipoxygenase. TGF- $\alpha$ activates $\mathrm{CPLA}_{2}$ (Li et al., 1997) and upregulates the expression of COX II mRNA and protein (Li et al., 1996) in differentiated hen granulosa cells, resulting in increased 
prostaglandin synthesis ( $\mathrm{Li}$ and Tsang, 1994, 1995). Although TGF- $\alpha$ attenuates serum deprivation-induced granulosa cell apoptosis in rats (Tilly et al., 1992) and hens (Johnson et al., 1996), it is not known whether prostaglandins mediate the anti-apoptotic action of TGF- $\alpha$.

The present study investigated the possible role of prostaglandins in the suppression of granulosa cell apoptosis by TGF- $\alpha$ in vitro.

\section{Materials and Methods}

\section{Reagents}

QIAamp blood kit and QIAquick nucleotide removal kit were purchased from Qiagen Inc. (Chatsworth, CA). Arachidonyl trifluoromethyl ketone (TFMK), N-(2cyclohexyloxy-4-nitrophenyl)methanesulfonamide (NS398) and arachidonic acid were purchased from Cayman Chemical Company (Ann Arbor, MI). Culture media (minimum essential medium (MEM) and M199), culture media reagents (L-glutamine, non-essential amino acids, penicillin, streptomycin and fungizone) and fetal bovine serum (FBS) were purchased from Gibco/Bethesda Research Laboratories (Burlington, Ontario). Hydroxyethylpiperazine ethanesulfonic acid (Hepes) was obtained from $\mathrm{BDH}$ (Toronto, Ontario). Klenow polymerase was purchased from New England Biolabs (Beverly, MA). $\alpha$-[32P]dCTP $(250 \mu \mathrm{Ci}$ per vial) was obtained from Amersham Life Science (Oakville, Ontario). Recombinant human transforming growth factor alpha (TGF- $\alpha$ ) was purchased from Collaborative Research (Bedford, MA). 2-p-amylcinnamoyl amino-4-chlorobenzoic acid (ONO-RS-82), agarose, aristolochic acid and Hoescht 33258 dye were obtained from Sigma Chemical Co. (St Louis, MO). [5,6,8,9,11,12,14,15$\left.{ }^{3} \mathrm{H}(\mathrm{N})\right]-\mathrm{PGF}_{2 \alpha}$ and $\left[3,6,8,11,12,14,15-{ }^{3} \mathrm{H}(\mathrm{N})\right]-\mathrm{PGE}_{2}$ (100$200 \mathrm{Ci}$ per $\mathrm{mmol}$ ) and scintillation fluid (ScintiVerse) were obtained from Dupont/NEN Research Products (Mississauga, Ontario). Charcoal, dextran, gelatin and eosin $\mathrm{Y}$ were purchased from Fisher Scientific (Nepean, ON). Prostaglandins $\left(\mathrm{PGE}_{1}, \mathrm{PGE}_{2}\right.$ and $\left.\mathrm{PGF}_{2 \alpha}\right)$ were purchased from Biomol Research Laboratories, Inc. (Plymouth Meeting, $\mathrm{PA})$. $\mathrm{PGE}_{2}$ and $\mathrm{PGF}_{2}$ antisera were gifts from N. R. Mason (Lilly Research Laboratories, Indianapolis, IN) and D. T. Armstrong (University of Western Ontario, London, Ontario), respectively.

\section{Isolation and culture of granulosa cells}

White Leghorn hens (Berry's Egg Farm, Kempville, ON) in their first year of egg laying were caged individually in an air conditioned $\left(22^{\circ} \mathrm{C}\right)$ windowless room under a $14 \mathrm{~h}$ light:10 h dark photoperiod with free access to food and water. Hens were monitored to determine the pattern of egg laying and were killed approximately 10-13 h after egg laying. These studies were carried out in accordance with the Guides of the Canadian Council on Animal Care on the use and handling of experimental animals and approved by the Animal Care Committee of the Loeb Health Research
Institute. Ovaries were excised and placed in cold medium 199 supplemented with Hepes (25 mmol l-1, pH 7.4). Granulosa cell layers from approximately 30 morphologically healthy prehierarchical follicles (round, not flaccid and yolk filled; 2-6 $\mathrm{mm}$ in diameter) were isolated, pooled and dissociated by treatment with medium 199 containing collagenase $\left(270 \mathrm{U} \mathrm{ml}^{-1}\right)$ and trypsin inhibitor $(0.01 \% \mathrm{w} / \mathrm{v}$; $\left.37^{\circ} \mathrm{C}, 5-10 \mathrm{~min}\right)$. Granulosa cell viability, as determined by the trypan blue exclusion test, was over $90 \%$. Granulosa cells $\left(1 \times 10^{6}\right.$ per dish) were plated $\left(6 \mathrm{~h}, 37^{\circ} \mathrm{C}\right)$ in $35 \mathrm{~mm}$ plastic dishes in $1 \mathrm{ml}$ MEM (supplemented with L-glutamine (0.29 $\left.\mathrm{mg} \mathrm{ml}^{-1}\right)$, non-essential amino acids $\left(0.1 \mathrm{mmol} \mathrm{I}^{-1}\right)$, streptomycin $\left(100 \mu \mathrm{g} \mathrm{ml}^{-1}\right)$ and penicillin (100 iu ml-1) containing $10 \%$ FBS under an atmosphere of $5 \% \mathrm{CO}_{2}$ and $95 \%$ air, and cultured for an additional $24 \mathrm{~h}$ in $1.5 \mathrm{ml}$ of either fresh MEM with FBS (10\%), or serum-free MEM containing various test agents (TGF- $\alpha, \mathrm{COX}$ or $\mathrm{PLA}_{2}$ inhibitors, prostaglandins or arachidonic acid). The change of media at the end of the plating period $(6 \mathrm{~h})$ also served to remove floating (or dead) cells, leaving 'healthy' cells tightly adherent to the culture surface. Thus, only viable undifferentiated granulosa cells from prehierarchical follicles were used. At the end of the culture period, media were collected and centrifuged ( $5 \mathrm{~min}, 10000 \mathrm{~g}$ ) to remove any floating cells. The cell-free media was supplemented with $2.0 \mathrm{ml}$ absolute ethanol for prostaglandin assay, whereas the cells recovered after centrifugation as well as those attached to the culture dish were pooled and stored at $-80^{\circ} \mathrm{C}$, pending DNA extraction.

\section{Prostaglandin measurements}

Appropriate volumes of the culture media (in duplicates) were analysed for PGE and PGF by radioimmunoassay as described by Jaffe et al. (1973). $\mathrm{PGE}_{2}$ and $\mathrm{PGF}_{2 \alpha}$ were used as standards. Since the antisera against $\mathrm{PGE}_{2}$ and $\mathrm{PGF}_{2 \alpha}$ had significant crossreactivity against $\mathrm{PGE}_{1}(16.8 \%)$ and $\mathrm{PGF}_{1 \alpha}$ (125.0\%), respectively (Lewis et al., 1978; Evans et al., 1981), the data are reported as PGE and PGF equivalents. Prostaglandin production in each treatment group was normalized against total cell protein content, as determined by the Bio-Rad protein assay.

\section{Biochemical assessment of apoptosis (DNA ladders)}

DNA was isolated using the QIAamp blood kit following the manufacturer's instructions. Briefly, cells were lysed and subjected to RNase and proteinase K treatment. Samples were loaded on to spin columns containing silica membranes, which specifically bound DNA (80 bp to $50 \mathrm{~kb}$ in size) and DNA was eluted with Tris buffer $\left(10 \mathrm{mmol} \mathrm{I}^{-1}\right.$, $\mathrm{pH}$ 9). DNA (500 ng) from each sample was radiolabelled with $\alpha-\left[{ }^{32} \mathrm{P}\right] \mathrm{dCTP}$, using the Klenow reaction as described by Rosl (1992) to quantify the extent of DNA fragmentation in cultured cells. Radiolabelled DNA was resolved by agarose (2\%) gel electrophoresis in Tris-acetate EDTA buffer (40 mmol Tris $\mathrm{I}^{-1}, 20 \mathrm{mmol}$ glacial acetic acid I-1, $1 \mathrm{mmol}$ EDTA ${ }^{-1}$ ) for about 150 min at $60-85 \mathrm{~V}$. The gel was dried 
and exposed to X-ray film or a phosphor screen for 0.5-24.0 h. The intensity of labelled low molecular mass (fragmented) DNA of $15 \mathrm{~kb}$ or less in each lane was determined using Molecular Dynamics Phosphorimager (Bio-Rad, Mississauga, ON).

\section{Morphological assessment of apoptosis}

At the end of the culture period, cells were detached from the culture surface by trypsin treatment $\left(0.025 \mathrm{~g} \mathrm{ml}^{-1}\right.$ in PBS; $37^{\circ} \mathrm{C} ; 2 \mathrm{~min}$ ) and combined with the floating cells from the medium. Cells were fixed with $37 \%$ formaldehyde $(10 \% ; v / v)$ and incubated with the nuclear stain Hoechst 33258 ( $2 \mu \mathrm{g} \mathrm{ml}^{-1}$ in PBS; $10 \mathrm{~min}$ ). An aliquot of the cell suspension was placed on a glass slide, viewed under UV light and photographed at a magnification of $\times 250$. Cells with fragmented or highly condensed (brightly stained) nuclei were considered apoptotic. Between 75 and 220 cells were counted per treatment group in each experiment.

\section{Statistical analysis}

Data represent results from at least three experiments and were analysed statistically by one-way ANOVA. Significant differences between groups were determined by the Newman-Kuel's test. Statistical difference was inferred at $P<0.05$.

\section{Results}

\section{Effect of TGF- $\alpha$ on serum deprivation-induced apoptosis}

Granulosa cells cultured in serum-free medium for $24 \mathrm{~h}$ showed spontaneous apoptotic DNA fragmentation, which was significantly suppressed by the presence of $10 \%$ FBS (Fig. 1a,b). TGF- $\alpha\left(5-100 \mathrm{ng} \mathrm{m}^{-1}\right)$ also inhibited apoptotic DNA fragmentation in a concentration-dependent manner in the absence of FBS. Maximum inhibition was observed at a concentration of $20 \mathrm{ng}$ TGF- $\alpha \mathrm{ml}^{-1}$, which decreased the serum deprivation-induced DNA fragmentation by $70 \%$ (Fig. 1a,b) and significantly reduced the proportion of apoptotic granulosa cells $(18 \%$ under serum deprivation versus $4 \%$ in the presence of TGF- $\alpha$; Fig. $2 \mathrm{c}$ ). The ID $\mathrm{ID}_{50}$ value for TGF- $\alpha$ in the suppression of DNA fragmentation (induced by serum withdrawal) was approximately $5 \mathrm{ng} \mathrm{ml}^{-1}$ (Fig. 1b).

\section{Effect of TGF- $\alpha$ on prostaglandin production}

If prostaglandins mediate the action of TGF- $\alpha$ in granulosa cells, prostaglandin synthesis would be expected to be stimulated by TGF- $\alpha$. Granulosa cells secreted appreciable amounts of PGE (12.9 \pm 1.9 pmol per $10^{6}$ cells $)$ and PGF $\left(39.6 \pm 3.3 \mathrm{pmol}\right.$ per $10^{6}$ cells) during a $24 \mathrm{~h}$ culture period in serum-free medium containing no exogenous TGF- $\alpha$. The addition of TGF- $\alpha$ (5-100 $\mathrm{ng} \mathrm{ml}^{-1}$ ) to the cell cultures significantly $(P<0.01)$ increased both PGE and PGF secretion in a concentration-dependent manner (Fig. 1C). Maximum stimulation was observed at (a)

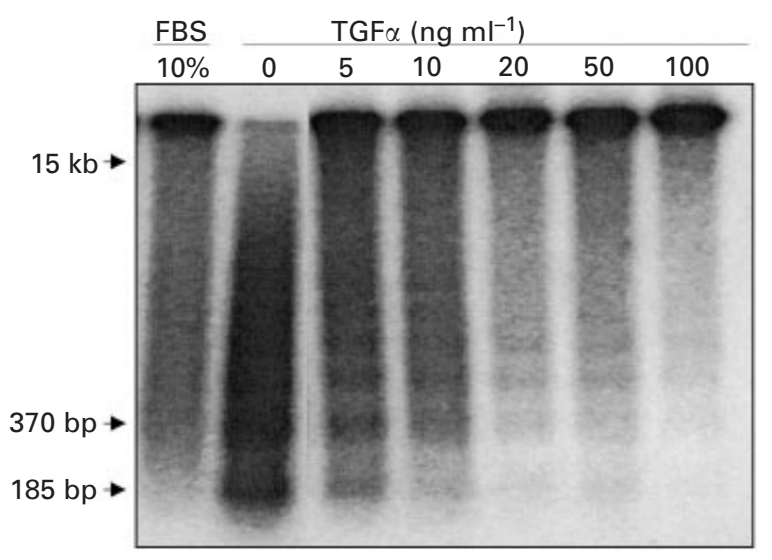

(b)

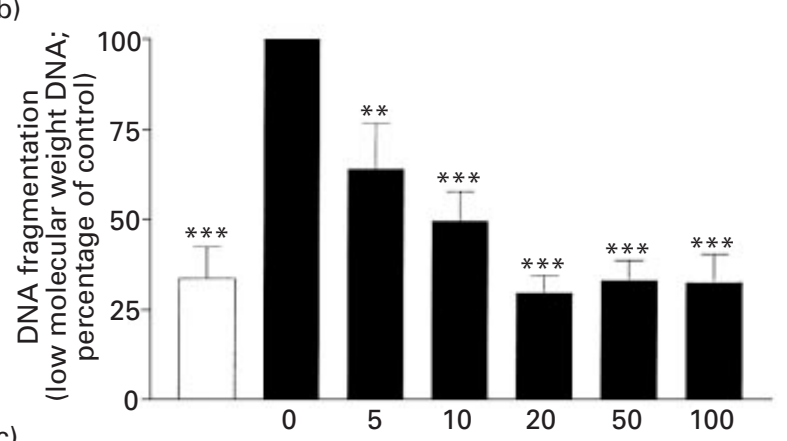

(c)

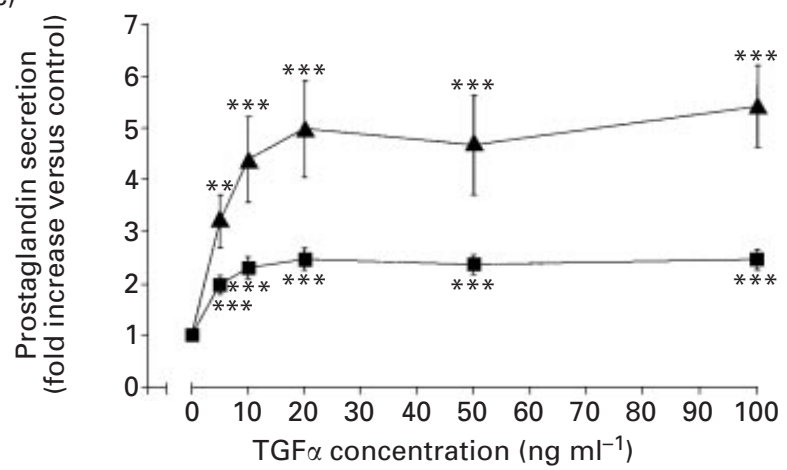

Fig. 1. Suppression of apoptosis induced by serum deprivation and stimulation of prostaglandin synthesis in hen granulosa cells by transforming growth factor $\alpha$ (TGF- $\alpha$ ) in vitro. Granulosa cells were cultured for $24 \mathrm{~h}$ in serum-free media containing $0,5,10,20,50$ or 100 ng TGF- $\alpha \mathrm{ml}^{-1}(\mathrm{~b} ; \mathbf{\square})$ or in media containing only $10 \%$ fetal bovine serum (FBS) (b; $\square$ ). DNA was isolated, radiolabelled with $\left[\alpha^{32} \mathrm{P}\right] \mathrm{dCTP}$ and resolved by agarose gel electrophoresis. (a) Representative autoradiogram showing apoptotic DNA ladders. (b) Densitometric quantification of the low molecular weight DNA $(\leqslant 15 \mathrm{~kb})$, corresponding to the DNA ladders (a). Data are expressed as mean ( \pm SEM) percentage of control (in the absence of TGF- $\alpha$ ); $n=4-5$ experiments. (c) Prostaglandin secretion in response to TGF- $\alpha$, as determined by radioimmunoassay. PGE $(\mathbf{\square})$ and PGF $(\mathbf{\Lambda})$ secretion in the control group (in the absence of TGF- $\alpha$; defined as 1) was $12.9 \pm 1.9$ pmol per $10^{6}$ cells and $39.6 \pm 3.3$ pmol per $10^{6}$ cells, respectively. Data are expressed as mean ( \pm SEM) fold increase over control; $n=9$ (PGE) and $n=6$ (PGF) experiments. ${ }^{* *} P<0.01$ versus control; ${ }^{* * *} P<0.001$ versus control. 
$20 \mathrm{ng} \mathrm{ml}^{-1}$, which increased the secretion of PGE and PGF to 2.5- and 4.5-fold above that of the control, respectively. The $\mathrm{ED}_{50}$ value for TGF- $\alpha$ in both PGE and PGF secretion was $5 \mathrm{ng} \mathrm{ml}^{-1}$, which was similar to its $\mathrm{ID}_{50}$ value for inhibition of serum deprivation-induced DNA fragmentation (Fig. 1b,c).

\section{Effect of PLA $A_{2}$ and COX inhibitors on TGF- $\alpha$-induced prostaglandin production and suppression of apoptosis}

COX and $\mathrm{PLA}_{2}$ inhibitors were used to block prostaglandin synthesis to determine whether TGF- $\alpha$-induced prostaglandin synthesis mediates the anti-apoptotic action of TGF- $\alpha$. Granulosa cells were cultured for $24 \mathrm{~h}$ in serumfree media containing TGF- $\alpha\left(20 \mathrm{ng} \mathrm{ml}^{-1}\right)$ and either a COX inhibitor (NS398 (5-10 $\left.\mu \mathrm{mol} \mathrm{I}^{-1}\right)$, ibuprofen (50-100 $\mu \mathrm{mol} \mathrm{I}^{-1}$ ) or indomethacin $\left.\left(12.5-25.0 \mu \mathrm{mol} \mathrm{I}^{-1}\right)\right)$ or a $\mathrm{PLA}_{2}$ inhibitor (aristolochic acid $\left(20-30 \mu \mathrm{mol} \mathrm{I}^{-1}\right)$, TFMK $\left(5-10 \mu \mathrm{mol} \mathrm{I}^{-1}\right)$, or ONO-RS-82 (5-10 $\left.\left.\mu \mathrm{mol} \mathrm{I}^{-1}\right)\right)$. The COX inhibitors NS398 and ibuprofen, but not indomethacin, effectively attenuated the TGF- $\alpha$-induced suppression of granulosa cell apoptosis (Fig. 3a,c,e). NS398 (5 $\mathrm{mol} \mathrm{I}^{-1}$ ) significantly increased $(180 \% ; P<0.05)$ apoptotic DNA fragmentation compared with control cells (Fig. 3), and a concentration-dependent effect of the inhibitor was observed when a lower concentration range of the inhibitor was used $(0,1$ and $10 \mu \mathrm{mol} \mathrm{I}^{-1}$; Fig. 2c) in assessment of nuclear morphology (proportion of apoptotic cells: $4 \pm 0.2 \%$ (control), $8 \pm 0.4 \%$ $\left.\left(1 \mu \mathrm{mol} \mathrm{I}^{-1} \quad \mathrm{NS} 398\right), \quad 16 \pm 1.9 \% \quad\left(10 \mu \mathrm{mol} \mathrm{I}^{-1} \quad \mathrm{NS} 398\right)\right)$. All three $\mathrm{PLA}_{2}$ inhibitors significantly induced, in a concentration-dependent manner and with various degrees of effectiveness, more extensive apoptotic DNA fragmentation in granulosa cells compared with TGF- $\alpha$-treated control cultures containing no inhibitor (Fig. 3b,d,f). The addition of each COX inhibitor to the cell cultures, even at its lowest concentration, caused complete (approximately $100 \%)$ inhibition of prostaglandin synthesis $(P<0.001$; Fig. $4 a, c, e)$. The addition of $\mathrm{PLA}_{2}$ inhibitors to the cell cultures also significantly $(P<0.001)$ suppressed the TGF$\alpha$-induced prostaglandin secretion (Fig. $4 b, d, f)$. Aristolochic acid suppressed PGE and PGF secretion in a concentrationdependent manner: at $20 \mu \mathrm{mol}$ aristolochic acid $\mathrm{I}^{-1} 35$ and $55 \%$ inhibition, respectively, was noted. TFMK and ONORS-82, at concentrations as low as $5 \mu \mathrm{mol} \mathrm{I}^{-1}$, inhibited the secretion of both prostaglandins to a similar extent and elicited maximum inhibition of PGE and PGF secretion (75 and $82 \%$, respectively).

\section{Effect of exogenous prostaglandins and arachidonic acid on the apoptotic effect of COX (NS398) and PLA $A_{2}$ (aristolochic acid) inhibitors}

The ability of exogenous prostaglandins and arachidonic acid to prevent the effect of NS398 and aristolochic acid, respectively, was studied to determine whether inhibitorinduced DNA fragmentation was a consequence of nonspecific effects of the inhibitors. $\mathrm{PGE}_{1}, \mathrm{PGE}_{2}$ or $\mathrm{PGF}_{2 \alpha}$ (1 or $\left.20 \mu \mathrm{mol} \mathrm{I}^{-1}\right)$ effectively inhibited NS398 (10 $\left.\mu \mathrm{mol} \mathrm{I}^{-1}\right)$ - induced apoptotic DNA fragmentation (Fig. 2a,b) and, $\mathrm{PGF}_{2 \alpha}\left(20 \mu \mathrm{mol} \mathrm{I}^{-1}\right)$ also inhibited the apoptotic changes in nuclear morphology (Fig. 2c). These data confirmed that the effect of NS398 was related to its inhibition of prostaglandin synthesis, and that the anti-apoptotic action of TGF- $\alpha$ may be mediated by prostaglandins. Similarly, the presence of arachidonic acid $\left(0.5 \mu \mathrm{mol} \mathrm{I}{ }^{-1}\right)$ completely inhibited the aristolochic acid $\left(30 \mu \mathrm{mol} \mathrm{I}^{-1}\right)$-induced apoptotic DNA fragmentation $(P<0.01$; Fig. 5a,b). In contrast, exogenous $\mathrm{PGE}_{1}, \mathrm{PGE}_{2}$ or $\mathrm{PGF}_{2 \alpha}$, at concentrations that effectively attenuated the COX inhibitor-induced apoptosis (1 or $20 \mu \mathrm{mol} \mathrm{I}{ }^{-1}$ ), failed to inhibit the aristolochic acid-induced DNA fragmentation (Fig. 6a,b).

\section{Potential of prostaglandins and arachidonic acid to mimic the anti-apoptotic action of TGF-a}

Granulosa cells were cultured in serum-free medium in the presence or absence of $\mathrm{PGF}_{2 \alpha}\left(20.0 \mu \mathrm{mol} \mathrm{I}^{-1}\right), \mathrm{PGE}_{1}$ $\left(20.0 \mu \mathrm{mol} \mathrm{I}^{-1}\right), \mathrm{PGE}_{2}\left(20.0 \mu \mathrm{mol} \mathrm{I}^{-1}\right)$, arachidonic acid $\left(0.5 \mu \mathrm{mol} \mathrm{I}^{-1}\right)$ or TGF- $\alpha\left(20.0 \mathrm{ng} \mathrm{m}^{-1}\right)$ to determine whether prostaglandins or arachidonic acid alone could mimic the anti-apoptotic action of TGF- $\alpha$. Compared with serum deprivation-induced DNA fragmentation (100\%), the presence of $\mathrm{PGF}_{2 \alpha}, \mathrm{PGE}_{1}, \mathrm{PGE}_{2}$ or arachidonic acid did not significantly affect the extent of apoptotic DNA fragmentation $(118 \pm 13 \%, 103 \pm 7 \%, 102 \pm 12 \%, 114 \pm 15 \%$, respectively; $n=4$ experiments).

\section{Discussion}

Hen granulosa cells from prehierarchical follicles (2-6 mm) cultured in serum-free medium underwent spontaneous apoptosis, as demonstrated by apoptotic DNA ladders and nuclear condensation. These results are in agreement with other reports of apoptosis induced by serum deprivation in hen granulosa cells from $4-8 \mathrm{~mm}$ follicles (Flaws et al., 1995), gonadotrophin-treated rat granulosa cells (Tilly et al., 1992), and several non-ovarian types of cell (Raff, 1992; Thompson, 1995). Apoptosis induced by serum- or survival factor-deprivation in vitro, as observed in undifferentiated hen granulosa cells, indicates that these cells must be under the constant 'protective' influence of anti-apoptotic factors in vivo. When these cell survival factors are 'removed' in vitro, the tonic suppression of apoptosis is no longer present and, as a result, apoptosis occurs. In this context, the addition of TGF- $\alpha$ to granulosa cell cultures was demonstrated to inhibit the serum deprivation-induced granulosa cell apoptosis effectively, which is consistent with other reports on the suppression of apoptosis by EGF and TGF- $\alpha$ (Tilly et al., 1992; Johnson et al., 1996; Laufey et al., 1996; Reinartz et al., 1996; Janz and Van der kraak, 1997). Theca and granulosa cells of hen ovarian follicles express the highest concentrations of both TGF- $\alpha$ and its receptor during the prehierarchical stage of development (Onagbesan et al., 1994), indicating an autocrine or paracrine mode of action for TGF- $\alpha$. The role of TGF- $\alpha$ as a 
(a)

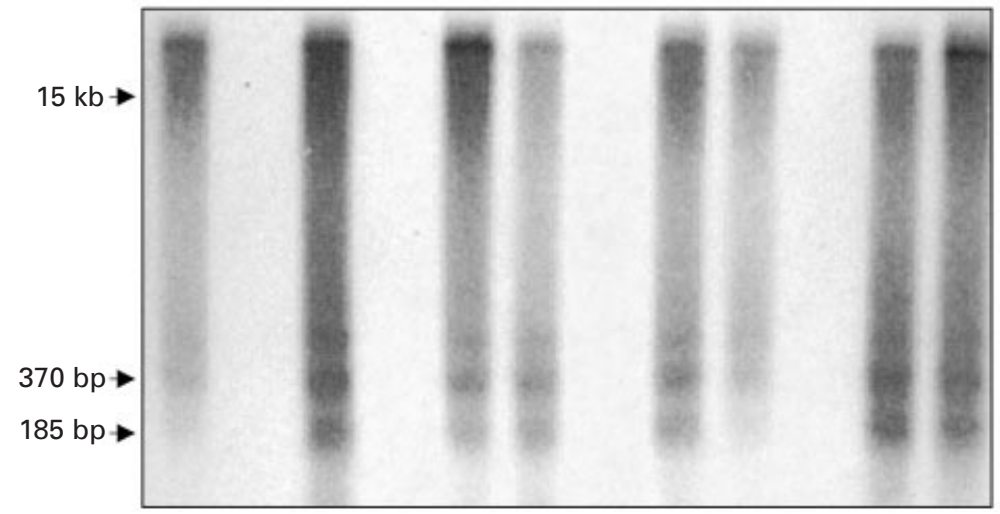

(b)
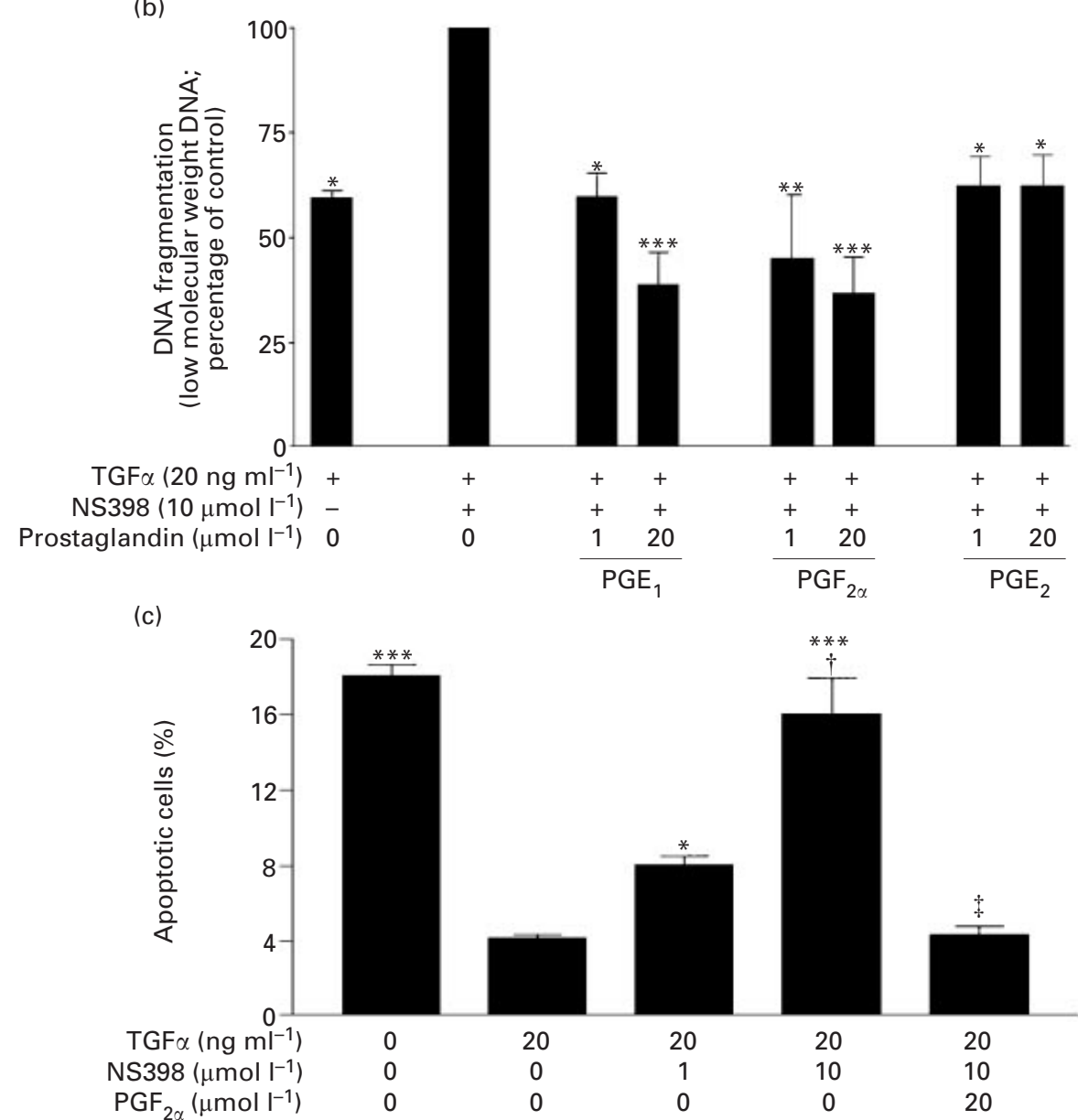

Fig. 2. Prevention of the 2-cyclohexyloxy-4-nitrophenyl methanesulfonamide (NS398)-induced apoptosis in hen granulosa cells by exogenous prostaglandins during a $24 \mathrm{~h}$ culture period. (a) Representative autoradiogram showing apoptotic DNA ladders. (b) Densitometric quantifications of the low molecular weight DNA $(\leqslant 15 \mathrm{~kb})$; corresponding histograms positioned directly below their DNA ladders in (a). Control (in the absence of prostaglandin but in the presence of transforming growth factor $\alpha($ TGF- $\alpha)\left(20 \mathrm{ng} \mathrm{ml}^{-1}\right)$ and NS398 $\left.\left(10 \mu \mathrm{mol} \mathrm{I}^{-1}\right)\right)$ is defined as $100 \%$. Data are expressed as mean ( \pm SEM) percentage of control; $n=3$ experiments. $* P<0.05$ versus control; ${ }^{* *} P<0.01$ versus control; ${ }^{* * *} P<0.001$ versus control. (c) The percentage of apoptotic cells as determined by nuclear morphology using Hoechst 33258. Granulosa cells were cultured in serum-free medium or serum-free medium containing the indicated test agents. Cells were stained with Hoechst 33258 and the percentage of apoptotic cells was determined by assessing nuclear morphology. Data are expressed as mean ( \pm SEM); $n=3-5$ experiments. ${ }^{*} P<0.05$ versus TGF- $\alpha$ alone; $* * * P<0.001$ versus TGF- $\alpha$ alone; $+P<0.001$ versus TGF- $\alpha$ plus NS398 $\left(1 \mu \mathrm{mol} \mathrm{I}^{-1}\right) ; \neq P<0.001$ versus TGF- $\alpha$ plus NS398 $\left(10 \mu \mathrm{mol} \mathrm{I}^{-1}\right)$. 

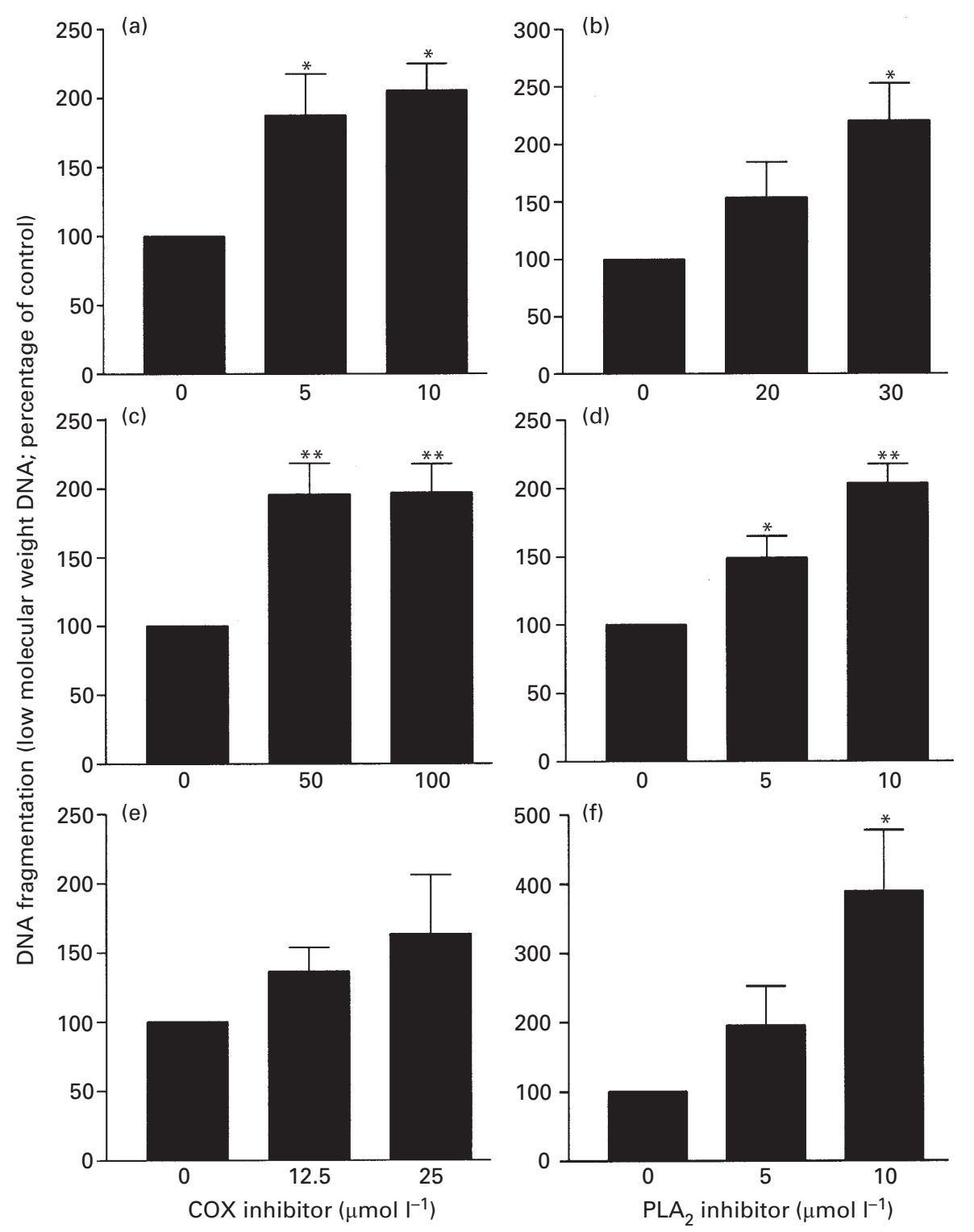

Fig. 3. Induction of apoptotic DNA fragmentation in hen granulosa cells by cyclooxygenase $(\mathrm{COX})$ inhibitors $(\mathrm{a}, \mathrm{c}, \mathrm{e})$ and phospholipase $\mathrm{A}_{2}\left(\mathrm{PLA}_{2}\right)(\mathrm{b}, \mathrm{d}, \mathrm{f})$ inhibitors in the presence of transforming growth factor $\alpha$ (TGF- $\alpha)\left(20 \mathrm{ng} \mathrm{ml}^{-1}\right)$ during a $24 \mathrm{~h}$ culture period. Cox inhibitors: (a) 2-cyclohexyloxy-4-nitrophenyl methanesulfonamide (NS398), (c) ibuprofen, (e) indomethacin. PLA 2 inhibitors: (b) aristolochic acid, (d) arachidonyl trifluro methyl ketone (TFMK), (f) 2-p-amylcinnamoyl amino-4-chlorobenzoic acid (ONO-RS-82). Histograms show densitometric quantification of the low molecular weight DNA ( $\leqslant 15 \mathrm{~kb}$ ). Control (20 ng TGF- $\alpha \mathrm{ml}^{-1}$; no inhibitor) is defined as $100 \%$. Data are expressed as mean ( \pm SEM) percentage of control; $n=3-7$ experiments. ${ }^{*} P<0.05$ versus control; ${ }^{* *} P<0.01$ versus control.

survival factor may be crucial at the prehierarchical stage of follicular development, as the undifferentiated granulosa cells from these follicles are much less responsive to gonadotrophins compared with differentiated granulosa cells from hierarchical and preovulatory hen follicles (Tilly et al., 1991a). However, up to $4 \%$ of the cultured granulosa cells were apoptotic even in the presence of the concentration of TGF- $\alpha$ that produced the maximum effect
(20 $\mathrm{ng} \mathrm{m}^{-1}$ ). This finding may be due to the inability of TGF- $\alpha$ in vitro to emulate the situation in vivo in which multiple apoptosis inhibitory (survival) factors may be impinging on the granulosa cells simultaneously. Alternatively, it is possible that such cells have already received a death signal and are destined to die, irrespective of the presence of survival factors in vivo.

Prostaglandins mediate the action of TGF- $\alpha$ in numerous 
(a)
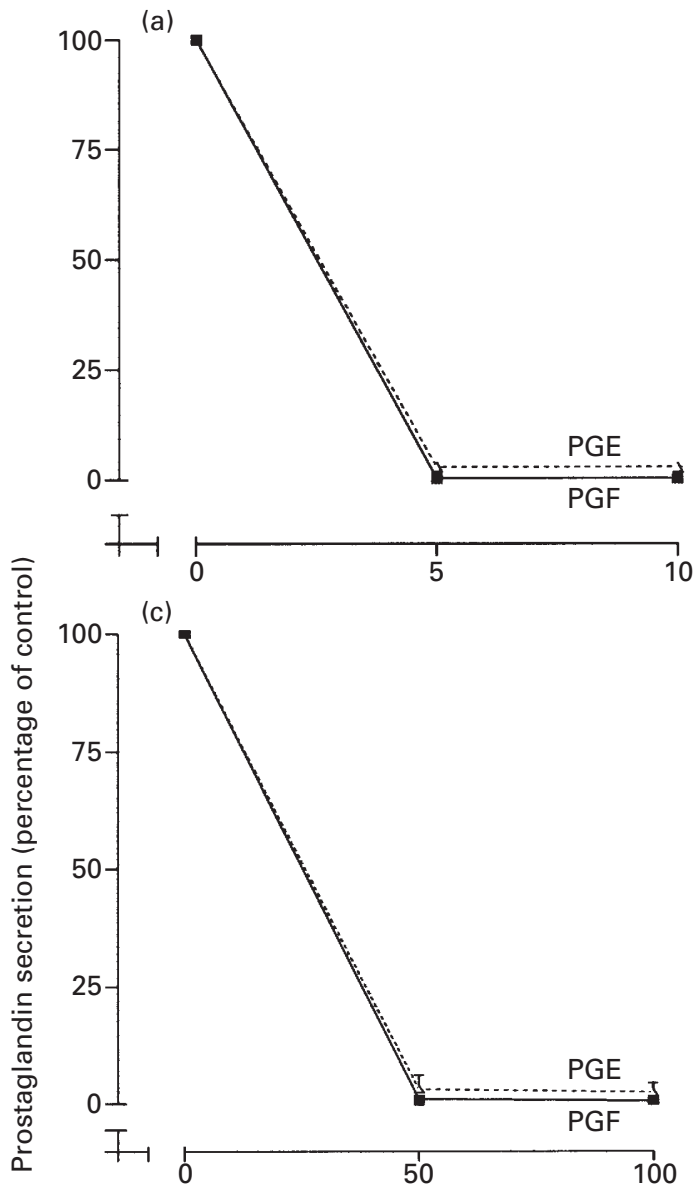

(e)

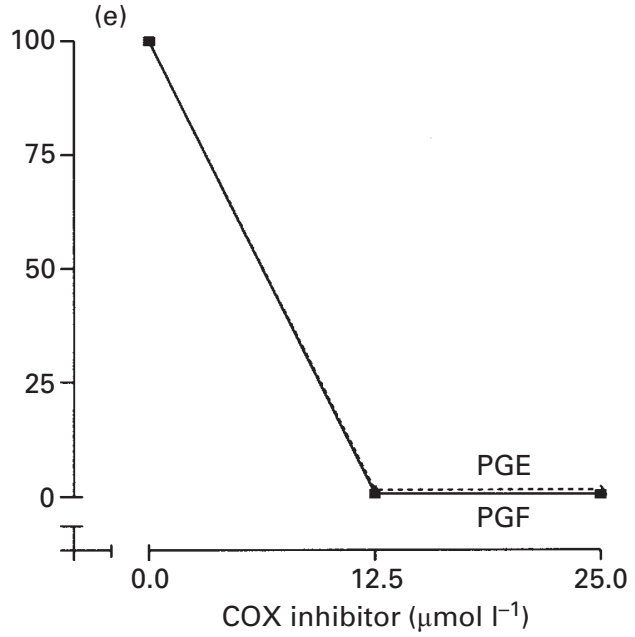

(b)

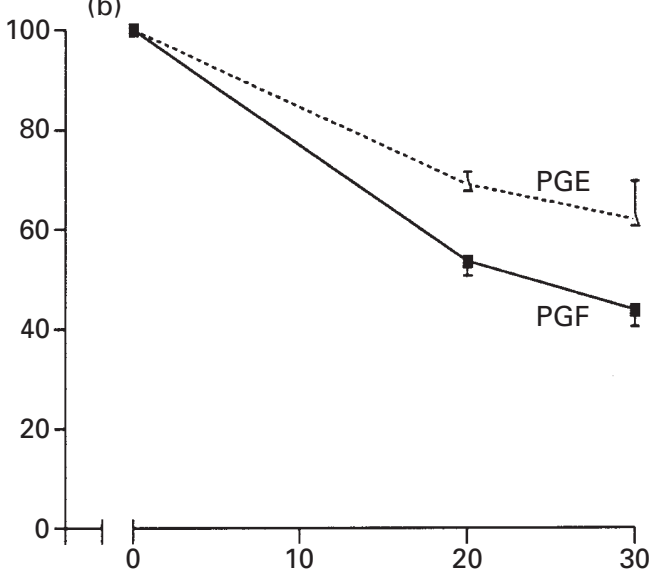

(d)
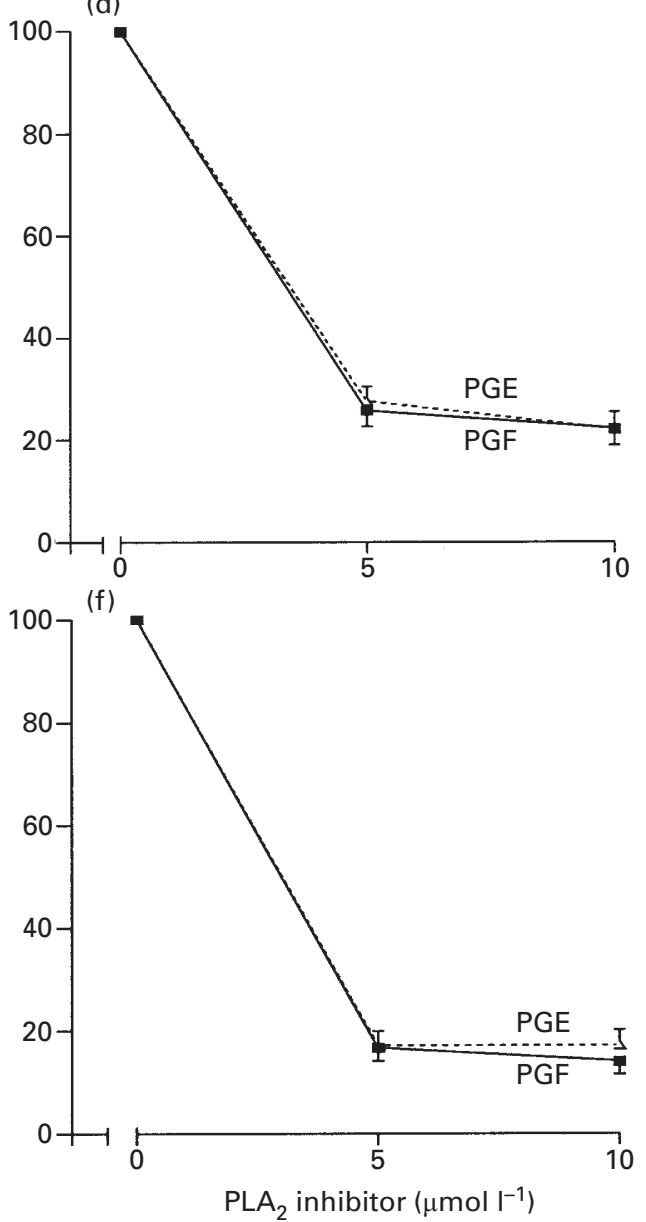

Fig. 4. Suppression of the transforming growth factor $\alpha$ (TGF- $\alpha$ )-induced prostaglandin secretion in hen granulosa cells by cyclooxygenase (COX) inhibitors $(a, c, e)$ and phospholipase $A_{2}\left(P L A_{2}\right)(b, d, f)$ inhibitors during a $24 \mathrm{~h}$ culture period. Cox inhibitors: (a) 2-cyclohexyloxy-4-nitrophenyl methanesulfonamide (NS398), (c) ibuprofen, (e) indomethacin. PLA 2 inhibitors: (b) aristolochic acid, (d) arachidonyl trifluro methyl ketone (TFMK), (f) 2-p-amylcinnamoyl amino-4-chlorobenzoic acid (ONO-RS-82). Prostaglandins secreted into the culture media were determined by radioimmunoassay. PGE and PGF secretion in the control group (20 ng TGF- $\alpha \mathrm{ml}^{-1}$, no inhibitor; defined as $100 \%$ ) was $30.0 \pm 3.8$ pmol per $10^{6}$ cells and $185.1 \pm 22.5$ pmol per $10^{6}$ cells, respectively. Data are expressed as mean ( \pm SEM) percentage of control; $n=5-8$ experiments. $P<0.001$ for each data point versus respective control. 


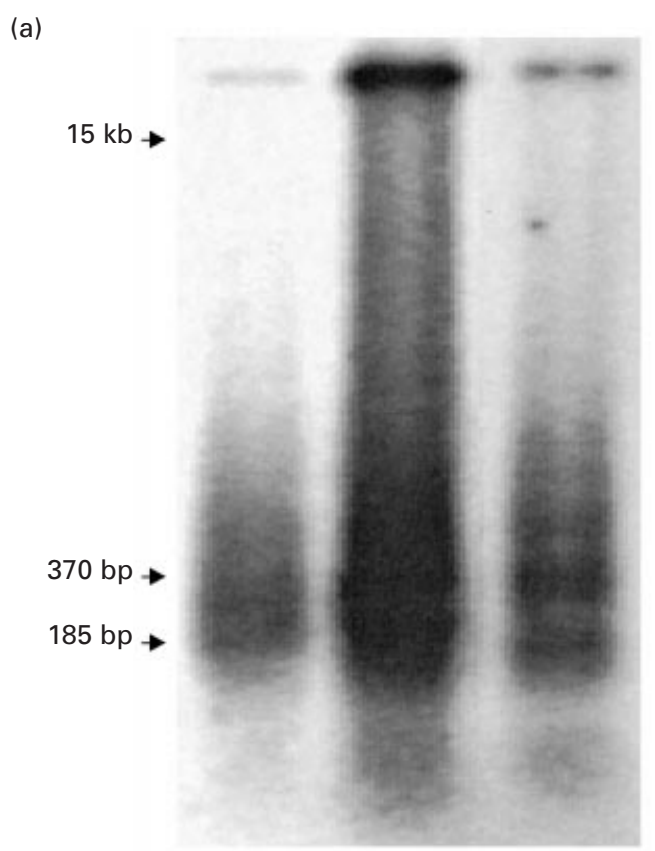

(b)

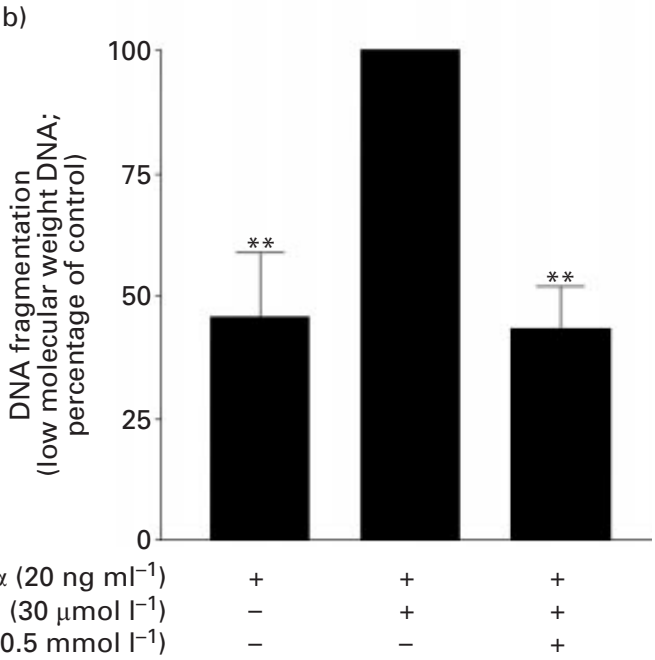

Fig. 5. Inhibition of the aristolochic acid-induced apoptosis in hen granulosa cells by arachidonic acid during a $24 \mathrm{~h}$ culture period. (a) Representative autoradiogram showing apoptotic DNA ladders. (b) Densitometric quantification of the low molecular weight DNA $(\leqslant 15 \mathrm{~kb})$; corresponding histograms for DNA ladder in (a). Control (transforming growth factor $\alpha$ (TGF- $\alpha$ ) plus aristolochic acid; no exogenous arachidonic acid (a)) is defined as $100 \%$. Data are expressed as mean ( \pm SEM) percentage of control; $n=4$ experiments. ${ }^{* * P}<0.01$ versus control.

physiological systems, including stimulation of DNA synthesis in differentiated hen granulosa cells (Li and Tsang, 1995) and in rat hepatocytes (Skouteris and McMenamin, 1992). However, it is unknown whether prostaglandins mediate the anti-apoptotic action of TGF- $\alpha$ in undifferentiated hen granulosa cells. In the present study, TGF- $\alpha\left(20 \mathrm{ng} \mathrm{ml}^{-1}\right)$

significantly increased the secretion of PGE and PGF in granulosa cells and suppressed changes induced by serum deprivation in cellular and nuclear morphology and DNA fragmentation characteristic of apoptosis. These observations are consistent with the concept that prostaglandins mediate the TGF- $\alpha$-induced suppression of granulosa cell apoptosis in vitro. Moreover, the addition of inhibitors of either COX or $\mathrm{PLA}_{2}$ to the culture media markedly suppressed the TGF- $\alpha$-induced prostaglandin synthesis and induced extensive granulosa cell apoptosis compared with TGF- $\alpha$-treated control cultures. The effect of the COX inhibitors was related to the suppression of prostaglandin synthesis and was not due to cytotoxicity, as exogenous prostaglandins $\left(\mathrm{PGF}_{2 \alpha}, \mathrm{PGE}_{1}, \mathrm{PGE}_{2}\right)$ were capable of inhibiting the apoptotic action of the inhibitor. These data provide evidence for the involvement of prostaglandins in the anti-apoptotic action of TGF- $\alpha$.

Although arachidonic acid also inhibited granulosa cell apoptosis induced by the $\mathrm{PLA}_{2}$ inhibitor aristolochic acid, exogenous $\mathrm{PGE}_{1}, \mathrm{PGE}_{2}$ or $\mathrm{PGF}_{2} \alpha$, at concentrations that effectively attenuated cell death induced by COX inhibitor ( 1 or $20 \mu \mathrm{mol} \mathrm{I}^{-1}$ ) were ineffective in inhibiting the aristolochic acid-induced apoptotic DNA fragmentation. It is suggested that prostaglandins are necessary (as demonstrated in studies with COX inhibitors) but not sufficient for mediating the anti-apoptotic action of TGF- $\alpha$. It is possible that, in addition to prostaglandins, arachidonic acid and its metabolites (that is, leukotrienes) may be important for the anti-apoptotic action of TGF- $\alpha$ in hen granulosa cells. In this context it should be noted that both prostaglandins and leukotrienes are produced after EGF stimulation in A431 cells and appear to be important in the physiological function of the growth factor (Peppelenbosch et al., 1993).

The mechanism by which prostaglandins suppress granulosa cell apoptosis in response to TGF- $\alpha$ is not known. It is possible that secreted prostaglandins may act via Gprotein coupled receptors (that is, EP and FP receptor subtypes) on granulosa cell membranes. However, as 8-bromo-cAMP and vasoactive intestinal peptide (known to act via the protein kinase A (PKA) pathway) prevent apoptosis induced by serum deprivation in undifferentiated hen granulosa cells (Flaws et al., 1995), it is unlikely that receptors primarily associated with the increase of intracellular cAMP (that is, $\mathrm{EP}_{2}$ and $\mathrm{EP}_{4}$ receptors) are involved in the action of PGF or PGE produced in response to TGF- $\alpha$. This notion is consistent with findings from the present study showing that prostaglandins alone (in the absence of TGF- $\alpha$ or serum) neither suppress nor enhance granulosa cell apoptosis induced by serum deprivation. Hence, prostaglandins require the presence of other, as yet undefined, factors downstream of TGF- $\alpha$ receptor activation to produce the anti-apoptotic action of TGF- $\alpha$. In granulosa cells, TGF- $\alpha$ and EGF exert their action via tyrosine kinase-dependent pathways (Tilly et al., 1992; Keel et al., 1995), mitogen-activated protein (MAP) kinase (Keel et al., 1995), protein kinase $\mathrm{C}$ and $\mathrm{Na}^{+} / \mathrm{H}^{+}$antiporter ( $\mathrm{Li}$ et al., 1991). Whether any of these TGF- $\alpha$-induced signals co- 
(a)

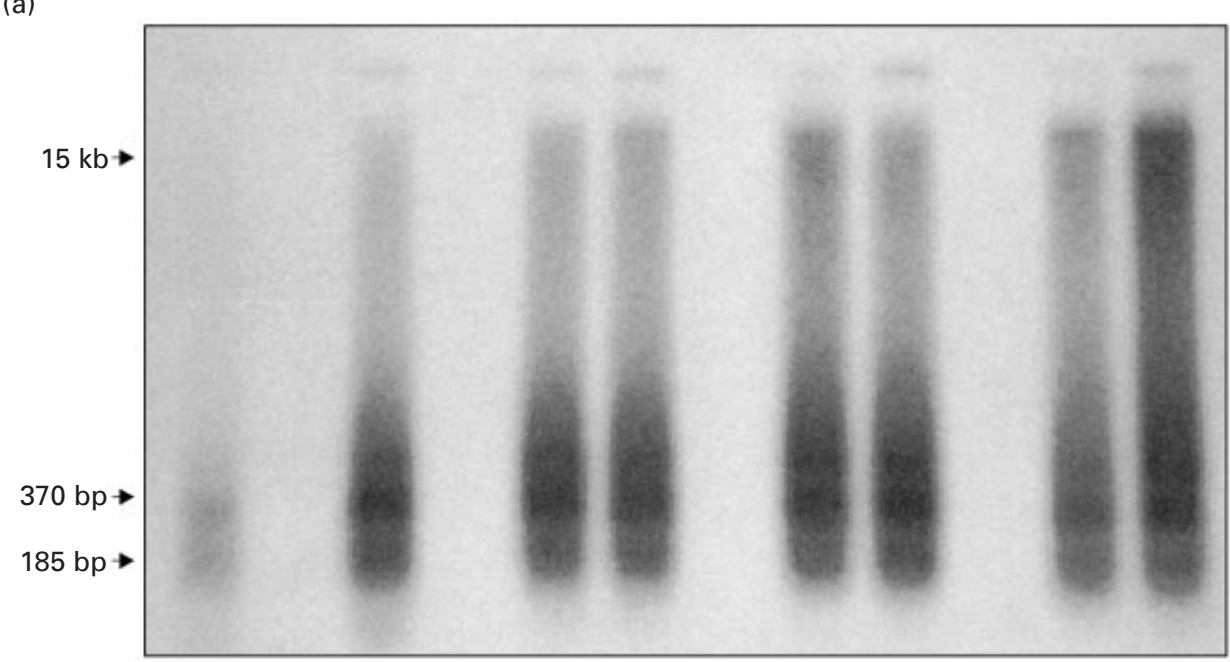

(b)

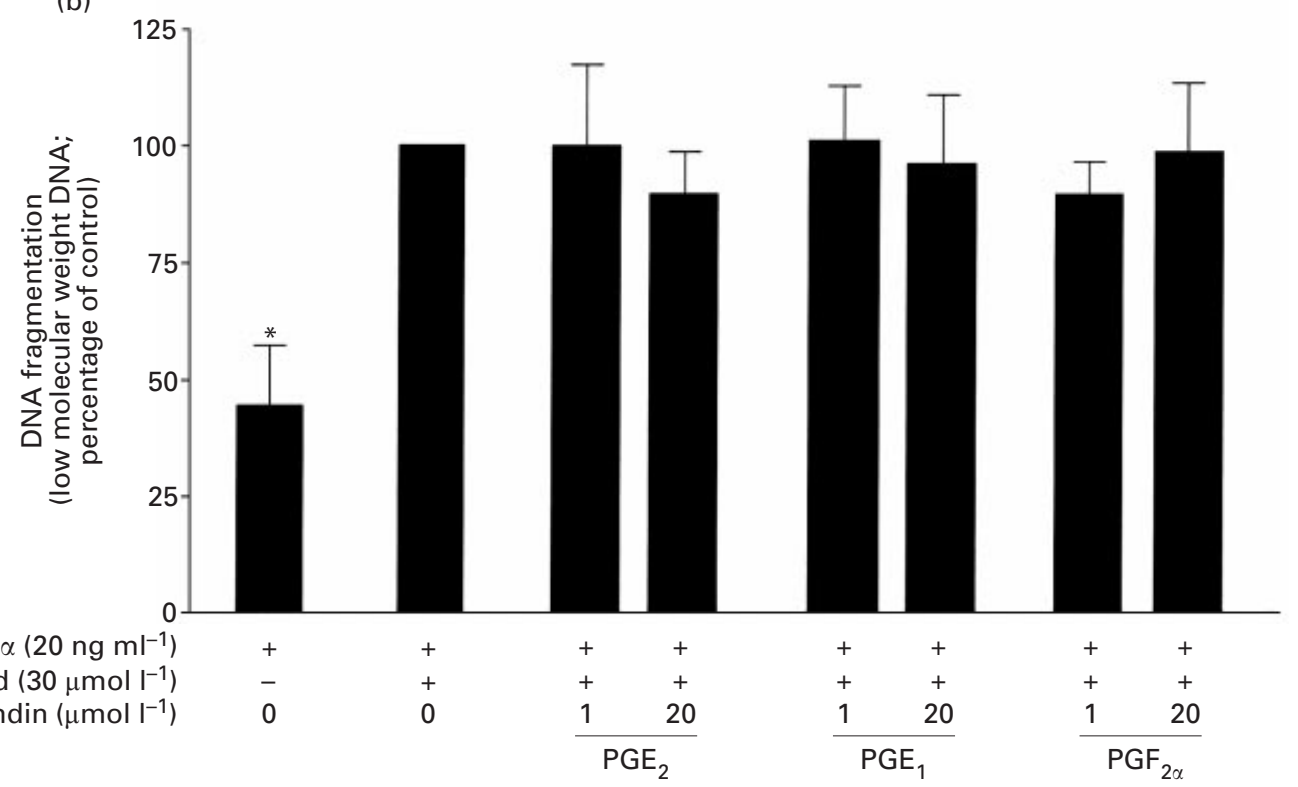

Fig. 6. Effect of prostaglandins on the aristolochic acid-induced apotosis in hen granulosa cells during a $24 \mathrm{~h}$ culture period. (a) Representative autoradiogram showing apoptotic DNA ladders. (b) Densitometric quantification of the low molecular weight DNA ( $\leqslant 15 \mathrm{~kb})$; corresponding histograms for DNA ladder in (a). Control (transforming growth factor $\alpha($ TGF- $\alpha$ ) plus aristolochic acid; no exogenous prostaglandins (a)) is defined as 100\%. Data are expressed as mean ( \pm SEM) percentage of control; $n=4$ experiments. $* P<0.05$ versus control.

operate with prostaglandins to effect the TGF- $\alpha$-mediated suppression of apoptosis is unknown. Preliminary studies from this laboratory have demonstrated that $\mathrm{EP}_{3}$ receptors, known to show high and similar affinity for $\mathrm{PGE}_{2}$ and $\mathrm{PGE}_{1}$ but low affinity for $\mathrm{PGF}_{2 \alpha}$, are present in hen granulosa cells (J. Li and B. K. Tsang, unpublished). $\mathrm{EP}_{3}$ receptor activation decreases CAMP concentrations by inhibiting adenylate cyclase (Negishi et al., 1995). Although human and bovine granulosa cells express $\mathrm{FP}$ and $\mathrm{EP}_{3}$ receptors (Tsai et al., 1996; Ristimaki et al., 1997), it is not known whether hen granulosa cells also express $\mathrm{FP}$ or $\mathrm{EP}_{1}$ receptors. Alternatively, prostaglandins may exert their effect in part via the peroxisome proliferator-activated receptor, a nuclear receptor that is activated by various fatty acids, including leukotriene B4 and prostaglandins of the A, D and J series (Yu et al., 1995; Devchand et al., 1996). Peroxisome proliferator-activated receptor is a transcription regulator that maintains lipid homeostasis in the liver, promotes adipocyte differentiation and controls the duration of the inflammatory response in the liver (Devchand et al., 1996; 
Shalev and Meier, 1996; Wolf, 1996). It is unknown whether granulosa cells express this receptor.

In summary, granulosa cell viability in vitro is dependent on the continual supply of survival and growth factors (for example, serum), and removal of such factors spontaneously induces apoptosis. In addition, the present study shows that TGF- $\alpha$ is a survival factor for undifferentiated hen granulosa cells, as demonstrated by the capacity of the growth factor to suppress serum deprivation-induced apoptosis. Prostaglandin synthesis is a necessary, but not sufficient, event in the suppression of granulosa cell apoptosis by TGF- $\alpha$. Whether arachidonic acid or leukotrienes are important in the anti-apoptotic action of TGF- $\alpha$ remains to be determined. It is possible that prehierarchical hen ovarian follicles need a continual supply of survival factors (such as TGF- $\alpha$ ) to maintain their viability and protect them from atresia. The availability of survival factors or the capacity of granulosa cells to respond to them may be important determinants of the fate of hen prehierarchical ovarian follicles (atresia versus ovulation).

This work was supported by a grant from the Canadian Institutes of Health Research (MOP-10369 to B. K. Tsang). R. Manchanda was a recipient of a Natural Sciences and Engineering Research Council of Canada Graduate Scholarship.

\section{References}

Chun SY, Eisenhauer KM, Minami S, Billig H, Perlas E and Hsueh AJW (1996) Hormonal regulation of apoptosis in early antral follicles: folliclestimulating hormone as a major survival factor Endocrinology 137 1447-1456

Devchand PR, Keller H, Peters JM, Vazquez M, Gonzalez FJ and Wahli W (1996) The PPARalpha-leukotriene pathway to inflammation control Nature 384 39-43

Evans CA, Kennedy TG, Patrick JE and Challis JRG (1981) Uterine prostaglandin concentration in sheep during late pregnancy and adrenocorticotropin-induced labor Endocrinology 109 1533-1538

Flaws JA, DeSanti A, Tilly KI, Javid RO, Kugu K, Johnson AL, Hirshfield AN and Tilly JL (1995) Vasoactive intestinal peptide-mediated suppression of apoptosis in the ovary: potential mechanisms of action and evidence of a conserved antiatretogenic role through evolution Endocrinology $1364351-4359$

Harrison JR (1994) Stimulation of $\mathrm{PGE}_{2}$ production by interleukin-1 and TGF $\alpha$ in osteoblastic MC3T3-E1 cells Journal of Bone and Mineral Research 9 817-823

Hirshfield AN and Midgley ARJ (1978) Morphometric analysis of follicular development in the rat Biology of Reproduction 19 597-605

Hughes FM, Jr and Gorospe WC (1991) Biochemical identification of apoptosis (programmed cell death) in granulosa cells: evidence for a potential mechanism underlying follicular atresia Endocrinology 129 2415-2422

Jaffe BM, Behrman HR and Parker CW (1973) Radioimmunoassay measurement of PGE, A and F in human placenta Journal of Clinical Investigation 54 398-405

Janz DM and Van der kraak G (1997) Suppression of apoptosis by gonadotropin, $17 \beta$-estradiol and epidermal growth factor in rainbow trout preovulatory ovarian follicles General and Comparative Endocrinology 105 186-193

Johnson AL, Bridgham JT, Witty JP and Tilly JL (1996) Susceptibility of avian granulosa cells to apoptosis is dependent upon stage of follicle development and is related to endogenous levels of bcl-xlong gene expression Endocrinology 137 2059-2066
Keel BA, Hilderbrandt JM, May JV and Davis JS (1995) Effects of epidermal growth factor on the tyrosine kinase phosphorylation of mitogenactivated protein kinase in monolayer cultures of porcine granulosa cells Endocrinology 136 1197-1204

Laufey TA, Sharyl JN, Guy JB, Johnson MD and Dickson RB (1996) Cooperation between TGF $\alpha$ and c-myc in mouse mammary tumorigenesis: coordinated expression of growth and suppression of apoptosis Oncogene $13757-765$

Lewis GS, Jenkins PE, Fogwell RL and Inskeep EK (1978) Concentration of prostaglandin $E_{2}$ and $F_{2}$ and their relationship to luteal function in early pregnant ewes Journal of Animal Science 47 1314-1323

Li J and Tsang BK (1994) Avian granulosa cell prostaglandin secretion is regulated by transforming growth factor $\alpha$ and $\beta$ and does not control plasminogen activator activity during follicular development Biology of Reproduction $\mathbf{5 1}$ 787-794

Li J and Tsang BK (1995) Prostaglandins mediate the stimulation of deoxyribonucleic acid synthesis by transforming growth factor $\alpha$ in hen granulosa cells during ovarian follicular development Biology of Reproduction 52 1050-1058

Li M, Morley P and Tsang BK (1991) Epidermal growth factor elevates intracellular $\mathrm{pH}$ in chicken granulosa cells by activating protein kinase $\mathrm{C}$ Endocrinology 129 2957-2964

Li J, Simmons DL and Tsang BK (1996) Regulation of hen granulosa cell prostaglandin production by transforming growth factors during follicular development: involvement of cyclooxygenase II Endocrinology 137 2522-2529

Li J, Li M and Tsang BK (1997) Regulation of cytosolic phospholipase $A_{2}$ in hen granulosa cells by transforming growth factors during follicular development Biology of Reproduction 57 929-935

Negishi M, Sugimoto Y and Ichikawa A (1995) Molecular mechanisms of diverse actions of prostanoid receptors Biochemica Biophysica Acta $1259109-120$

Onagbesan OM, Gullik W, Woolveridge I and Peddie MJ (1994) Immunohistochemical localization of epidermal growth factor receptor, epidermal-growth-factor-like and transforming-growth-factor-alpha-like peptide in chicken ovarian follicles Journal of Reproduction and Fertility 102 147-153

Peppelenbosch MP, Tertoolen LGJ, Hage WJ and de Laat SW (1993) Epidermal growth factor-induced actin remodelling is regulated by 5-lipoxygenase and cyclooxygenase products Cell 74 565-575

Raff MC (1992) Social controls on cell survival and cell death Nature 356 397-400

Reinartz J, Bechtel MJ and Kramer MD (1996) Tumor necrosis factor $\alpha$ induced apoptosis in human keratinocyte cell line (HaCat) is counteracted by transforming growth factor $\alpha$ Experimental Cell Research $\mathbf{2 2 8}$ 334-340

Ristimaki A, Jaatinen R and Ritvos O (1997) Regulation of prostaglandin $\mathrm{F}_{2 \alpha}$ receptor expression in cultured human granulosa-luteal cells Endocrinology 138 191-195

Rosl F (1992) A simple and rapid method for detection of apoptosis in human cells Nucleic Acids Research 20 5243-5250

Shalev A and Meier CA (1996) Peroxisome proliferator-activated receptors: a nuclear hormone receptor involved in adipocyte differentiation and lipid homeostasis European Journal of Endocrinology 134 541-542

Skouteris GG and McMenamin M (1992) TGF $\alpha$-induced DNA synthesis and c-myc expression in primary rat hepatocyte cultures is modulated by indomethacin Biochemical Journal 281 729-733

Thompson CB (1995) Apoptosis in the pathogenesis and treatment of disease Science 267 1456-1462

Tilly JL, Kowalski KI and Johnson AL (1991a) Stage of ovarian follicular development associated with the initiation of steroidogenic competence in avian granulosa cells Biology of Reproduction 44 305-314

Tilly JL, Kowalski KI, Johnson AL and Hsueh AJW (1991b) Involvement of apoptosis in ovarian follicular atresia and postovulatory regression Endocrinology 129 2799-2801

Tilly JL, Billig H, Kowalski KI and Hsueh AJW (1992) Epidermal growth factor and basic fibroblast growth factor suppress the spontaneous onset of apoptosis in cultured rat ovarian granulosa cells and follicles by a tyrosine kinase dependent mechanism Molecular Endocrinology 6 1942-1950 
Tsai SJ, Wiltbank MC, Meberg BM and Niswender GD (1996) Distinct mechanisms regulate induction of messenger ribonucleic acid for prostaglandin $\mathrm{G} / \mathrm{H}$ synthase-2, $\mathrm{PGE}\left(\mathrm{EP}_{3}\right)$ receptor, and $\mathrm{PGF}_{2 \alpha}$ receptor in bovine preovulatory follicles Endocrinology 137 3348-3355

Wolf G (1996) Adipocyte differentiation is regulated by a prostaglandin liganded to the nuclear peroxisome proliferator-activated receptor Nutrition Review $\mathbf{5 4}$ 290-292

Yu K, Bayona W, Kallen CB, Harding HP, Ravera CP, McMahon G, Brown M and Lazar MA (1995) Differential activation of peroxisome proliferator- activated receptors by eicosanoids Journal of Biological Chemistry $\mathbf{2 7 0}$ 23 975-23 983

Received 2 January 2001

First decision 7 February 2001.

Revised manuscript received 19 March 2001.

Accepted 21 March 2001. 